\title{
PSYCHIATRY, GENOCIDE AND THE NATIONAL SOCIALIST STATE: LESSONS LEARNT, IGNORED AND FORGOTTEN
}

\author{
Michael Robertson, Edwina Light, Wendy Lipworth \\ and Garry Walter
}

\section{Introduction}

The attempted genocide of European Jews perpetrated by the National Socialist regime in Germany and its collaborators was a distinctly modern event. The bureaucratised and industrialised nature of the Nazi plan (the Endlösung or Final Solution) is generally considered the defining characteristic of the Holocaust. Prior to the establishment of extermination camps in Poland, the Nazi regime had perpetrated or fomented both sporadic massacres and a militarised programme of executions in Eastern Europe, in what has been termed "Holocaust by bullets." ${ }^{1}$ Yet despite the murder of 1.5 million Jews by SS and police mobile killing squads (Einsatzgruppen), the defining symbol of the Holocaust was the industrialised killing centre at Auschwitz-Birkenau. Importantly, the gas chambers of the Reinhard camps (Belzec, Sobibor, and Treblinka II) and Auschwitz-Birkenau did not appear de novo for the purposes of killing Europe's Jews. ${ }^{2}$ The medical profession, in collusion with Adolf Hitler's Chancellery $(K d F)$, had earlier developed and refined a large-scale, state-financed and well-concealed program of victim selection and mass transportation to dedicated killing centres with effective techniques of gassing and disposal of victims' remains. The template for the Endlösung evolved as a medical procedure, developed primarily by psychiatrists. ${ }^{3}$

It is argued that the Holocaust may be conceptualised as not a "moment in history" but rather as the "hidden face" of the culture that persists. ${ }^{4}$ The involvement of psychiatrists in this highly organised programme thus raises questions relevant to the contemporary psychiatric profession. While facile comparisons of present-day ethical dilemmas in psychiatry with extreme acts

1 Patrick Desbois, The Holocaust by Bullets: A Priest's Journey to Uncover the Truth Behind the Murder of 1.5 Million Jews (New York: Palgrave Macmillan, 2008).

2 Henry Friedlander, The Origins of Nazi Genocide: From Euthanasia to the Final Solution (Chapel Hill: University of Noth Carolina Press, 1995).

3 Michael Burleigh, Death and Deliverance: “Euthanasia” in Germany 1900-1945 (London: Pan, 2002).

4 Zygmunt Bauman, Modernity and the Holocaust (Ithaca: Cornell University Press, 1989). 
of certain psychiatrists in the Nazi regime do little to enlighten psychiatric ethics and likely lead the discourse away from the contemporary significance of the period, some formulations of the Holocaust have utilised the concept of "biopower," 5 which along with the notion of a "dual role dilemma," provides a means to better understand current challenges in psychiatric ethics.

Biopower represents a means of governmental or state control of individual or population biology and is a modern progression from the coercive power of the sovereign to control life. The mass sterilisation or destruction of the sick and disabled under Nazism was a distinct application of biopower. Our argument is that through this particular programme of persecution of the sick and disabled, largely executed by the psychiatric profession, the Nazi regime created a biological "crisis" situated initially in the discourse of eugenics and later, racial hygiene. The regime used this as a pretext for a large-scale exercise of biopower over the Volk (population). This raised a specific crisis in psychiatric ethics: in the setting of a totalitarian state, the psychiatric profession was made responsible to the state and the health of the Volk, at the extreme expense of many individual patients. This, in turn, created a form of the dual-role dilemma.

The "dual role dilemma” was originally a construct from ethical discourse in forensic psychiatry, highlighting tension between the conflicting obligations of the psychiatrist to the patient and a third party, in that instance, the court system. Many dilemmas in psychiatric ethics can be reduced to manifestations of the dual role dilemma and, as we will argue, the situation of the psychiatric profession in the Nazi regime was one of history's greatest dual role dilemmas in that it placed the psychiatric profession in a tension between obligations to patients and to the regime and the Volk.

Most present-day psychiatrists acknowledge the role their profession played in the Nazi period (1933-1945). ${ }^{7}$ Much attention in this regard has been paid to human rights violations perpetrated against people with psychiatric, intellectual and physical disabilities. Both these abuses and the broader history of the German psychiatric profession in the Nazi regime offer many lessons for contemporary psychiatric ethics. In the first part of this essay, we provide a broad survey of the main themes in the history of the psychiatric

5 Michel Foucault, The Birth of Biopolitics: Lectures at the Collége de France, 1978-1979 (New York: Picador, 2004); Paul Rabinow and Nikolas Rose, “Biopower Today,” BioSocieties 1 (2006), 195-217; Giogio Agamben, Homo Sacer: Sovereign Power and Bare Life (Stanford: Stanford Univeristy Press, 1988).

6 Michael Robertson and Garry Walter, "Many Faces of the Dual-role Dilemma in Psychiatric Ethics," Australian and New Zealand Journal of Psychiatry 42, no. 3 (2008), 228-35.

7 Rael D. Strous, "Psychiatry During the Nazi Era: Ethical Lessons for the Modern Professional," Annals of General Psychiatry 6, no. 8 (2007); Michael von-Cranach, "Ethics in Psychiatry: The Lessons We Learn from Nazi Psychiatry,” Eur Arch Psychiatry Clin Neurosci 260 (2010), 152-56. 
profession in the Nazi regime. In the second part, we provide a deeper analysis of the significance of this period for contemporary psychiatric ethics.

\section{Part 1-A historical survey}

\section{Psychiatry before National Socialism}

Two iconic figures and two divergent views on mental illness characterised German psychiatry during the late nineteenth and early twentieth centuries. The work of Emil Kraepelin and Sigmund Freud left momentous clinical and cultural legacies to the present day. ${ }^{8}$ The differences between the two psychiatrists' projects broadly represented the split in the German psychiatric profession's views of mental illness at the time, regarding such illness as either a biological phenomenon (Somatiker) or a disease of the soul (Psychiker). ${ }^{9}$ Freud's ideas were rejected and demonised by both the German psychiatric profession and Nazi regime as the foundation of the "Jewish Science" of psychoanalysis. ${ }^{10}$ This void enabled Kraepelin's legacy to profoundly influence German psychiatry. Kraepelin's project included, inter alia, classification of psychiatric disorders and establishment of the paradigm of biological psychiatry, culminating in his founding the German Institute for Psychiatric Research. ${ }^{11}$ Kraepelin was drawn ultimately to the tenets of Social Darwinism, eugenics and racial hygiene, and the idea that society had countered natural selection and allowed dysfunctional genetic traits to flourish. He was concerned about "the number of idiots, epileptics, psychopaths, criminals, prostitutes, and tramps who descend from alcoholic and syphilitic parents, and who transfer their inferiority to their offspring," and argued that "our highly developed social welfare has the sad side-effect that it operates against the natural selfcleansing of our people." ${ }^{12}$ These ideas were developed further by devotees (including psychiatrist, eugenicist and Nazi, Ernst Rüdin), which ensured this

8 Hannah S. Decker, "How Kraepelinian was Kraepelin? How Kraepelinian are the Neo-Kraepelinians?-From Emil Kraepelin to DSM-III,” History of Psychiatry 18, no. 3 (2007), 337-60.

9 Albrecht Hirschmueller, trans. by Magda Whitrow, "The Development of Psychiatry and Neurology in the Nineteenth Century," History of Psychiatry x (1999), 395-423.

10 Geoffrey Cocks, Psychotherapy in the Third Reich: The Göring Institute (New York: Oxford University Press, 1985); James Goggin and Eileen Brockman-Goggin, Death of a Jewish Science: Psychoanalysis in the Third Reich (West Lafayette: Purdue University Press, 2001).

11 This institute would later become part of the main German academic body of the twentieth century, the Kaiser Wilhelm Society.

12 Martin Brüne, “On Human Self-Domestication, Psychiatry, and Eugenics,” Philosophy, Ethics and Humanities in Medicine 2, no. 1 (2007), 21. 
aspect of Kraepelin's work dominated interwar German psychiatry ${ }^{13}$ and was at the service of the National Socialists in their justification for genocide. ${ }^{14}$

In the early 1900s, a growing anti-psychiatry sentiment in Germany fostered debate over asylum care versus family care for the "insane," 15 although the systems of asylum (Irrenanstlaten) persisted as the locale of psychiatric practice. ${ }^{16}$ Asylums became the focal point of psychiatric clinical practice in the period leading up to the Nazi regime and consisted of Heilanstalten (sanatoria) and Pflegeanstalten (nursing homes or care institutions). From 1880 to 1920 , the number of asylum inmates in Germany increased by nearly 500 per cent. ${ }^{17}$ Patients in these asylums had always fared badly-nearly 70,000 German psychiatric patients died of starvation and other consequences of deprivation during World War One, ${ }^{18}$ and the high cost of maintaining these institutions was a constant concern for state treasuries. ${ }^{19}$

During the same period, psychiatrists began to expand their approaches to asylum patient care and treatment, including patient engagement in "work therapy" (Arbeitstherapie), akin to what many would recognise as occupational therapy today. ${ }^{20}$ The large numbers of psychiatric casualties from the 1914-1918 war had also prompted German psychiatrists to experiment with more radical therapies ${ }^{21}$ such as malaria therapy, ${ }^{22}$ aversion therapy ${ }^{23}$ and insulin coma therapy. ${ }^{24}$ This enabled a "reform” movement in German psychi-

13 Matthias Weber, “Ernst Rüdin, 1874-1952: A German Psychiatrist and Geneticist,” American Journal of Medical Genetics 67, no. 4 (1996), 323-31.

14 Eric Engstrom, Matthais Weber and Wolfgang Burgmair, "Emil Wilhelm Magnus Georg Kraepelin (1856-1926),” American Journal of Psychiatry 163, no. 10 (2006), 1710.

15 Heinz-Peter Schmiedebach, "Zerquälte Ergebnisse einer Dichterseele?-Literarische Kritik, Psychiatrie und Öffentlichkeit um 1900,” in Moderne Anstaltspsychiatrie im 19. und 20. Jahrhundert-Legitimation und Kritik, eds. Heiner Fangerau and Karen Nolte (Stuttgart: Franz Steiner, 2006).

16 Andreas Pernice and N.J.R. Evans, "Family Care and Asylum Psychiatry in the Nineteenth Century: The Controversy in the Allgemeine Zeitschrift fur Psychiatrie Between 1844 and 1902," History of Psychiatry 6, no. 21 (1995), 55-68.

17 Dirk Blasius, Einfache Seelenstörung: Geschichte der deutschen Psychiatrie 1800-1945 (Frankfurt am Main: Fischer, 1994).

18 Heinz Faulstich, Hungersterben in der Psychiatrie 1914-1949: mit einer Topographie der NS-Psychiatrie (Freiburg im Breisgau: Lambertus, 1998).

19 Michael Burleigh, “The Legacy of Nazi Medicine in Context,” in Medicine and Medical Ethics in Nazi Germany: Origins, Practices, Legacies, eds. Francis Nicosia and Jonathan Huener (New York: Berghahn Books, 2002).

20 Heinz-Peter Schmiedebach and Stefan Priebe, "Social Psychiatry in Germany in the Twentieth Century: Ideas and Models,” Medical History 48 (2004), 449-72.

21 Heinz-Peter Schmiedebach, "Psychiatry in Germany in the early 20th Century,” Neurology, Psychiatry and Brain Research 22, no. 2 (2016), 29-3.

22 Cynthia Tsay, "Julius Wagner-Jauregg and the Legacy of Malarial Therapy for the Treatment of General Paresis of the Insane,” Yale Journal of Biology and Medicine 86, no. 2 (2013), 245-54.

23 F. Kaufmann, "Die planmäßige Heilung komplizierter psychogener Bewegungsstörungen bei Soldaten in einer Sitzung,” Feldärtz Beilage Münch Med Wochenschr 63 (1916), $802 \mathrm{ff}$. 
atric asylums. ${ }^{25}$ Despite the introduction of such treatments, there remained a group of patients whose illness and disability proved intractable. This group's failure to respond to new treatment methods strengthened views about the financial costs and the perceived futility of their lives.

\section{The psychiatric profession and the Nazi regime}

After the National Socialists took power, the professions were subject to a process of alignment to the values of the Nazi regime. ${ }^{26}$ The Gleichschaltung (alignment) of the medical profession was positioned around notions of public health and hygiene. ${ }^{27}$ As part of the Gleichschaltung, Jewish physicians were subjected to restrictions to their medical practice, were forced out of their university posts or imprisoned. Around 50 per cent of German physicians joined either the Nazi party or associated bodies, ${ }^{28}$ and psychiatrists were enthusiastic participants in the regime. Motivations for participation in the NSDAP were variably political or ideological, or inspired by opportunism and institutional loyalty. ${ }^{29}$ The transcripts of criminal trials in West Germany of perpetrators of the Nazi "euthanasia" programme provide some insight into such motivations for participation in the murder of patients, including ideological affinity with Nazi doctrine, vanity and ambition, a distorted sense of obedience, "inertia" of the will, careerism and personality vulnerability. ${ }^{30}$ Other justifications include seemingly self-serving variations of the concept of empathy in that many of the killers sought to reframe the murder of the sick and disabled patients as

24 I. Murray Rossman and William B. Cline "The Pharmacological 'Shock' Treatment of Chronic Schizophrenia,” American Journal of Psychiatry 94, no. 6 (1938), 1323-36.

25 Edward Shorter, A History of Psychiatry: From the Era of the Asylum to the Age of Prozac (New York: Wiley, 1997).

26 Claudia Koonz, The Nazi Conscience (Cambridge, Mass: Bellknap, 2003).

27 Robert Jay Lifton, The Nazi Doctors: Medical Killing and the Psychology of Genocide (New York: Basic Books, 2000).

28 Omar Haque, Julian De Freitas, Ivana Viani, Bradley Niederschulte and Harold Bursztajn, "Why Did So Many German Doctors Join the Nazi Party Early?” International Journal of Law and Psychiatry 35, no. 5-6 (2012), 473-79.

29 Henry Friedlander, "Physicians as Killers in Nazi Germany: Hadamar, Treblinka, and Auschwitz,” in Medicine and Medical Ethics in Nazi Germany: Origins, Practices, Legacies, eds. Francis Nicosia and Jonathan Huener (New York: Berghahn Books, 2002); Michael Dudley and Fran Gale, "Psychiatrists As a Moral Community? Psychiatry Under the Nazis and its Contemporary Relevance," Australian and New Zealand Journal of Psychiatry 36, no. 5 (2002), 585-94.

30 Michael Bryant, Confronting the "Good Death”: Nazi Euthanasia on Trial, 1945-1953 (Boulder: University Press of Colorado, 2005). 
acts of mercy or benevolence. ${ }^{31}$ Some authors, however, define the motivation purely in terms of economic necessity. ${ }^{32}$

The primary theoretical underpinning of the Gleichschaltung in the case of German psychiatry was eugenics. ${ }^{33}$ The term "eugenics" usually refers to the improvement of the health of a population by the promotion of desirable heritable characteristics through the elimination of "inferior" genetic stock from the breeding pool. Although the concept dates to Plato, the modern term is attributed to British polymath Francis Galton. ${ }^{34}$ Despite its clear link to Kraepelin's ideas, eugenics was by no means solely a German phenomenon. In the early twentieth century, eugenic societies existed in numerous countries and grew in popularity in the face of the massive social change that followed World War One. ${ }^{35}$ This legitimated racist immigration policy, particularly in the US and Australia in the 1930s. ${ }^{36}$ Well before it was used for genocidal purposes, the conflation of genetics and race offered by eugenics enabled the Nazi regime to sanction its programme of social exclusion through "medical science” and establish a collaborative relationship with the German medical profession. Many influential psychiatrists were enthusiastic eugenicists, including the co-founder of the German Society for Racial Hygiene, Kraepelin's acolyte Ernst Rüdin. ${ }^{37}$

\section{Krankenmorde and the Holocaust}

Psychiatrists were not only keen advocates of the principles of eugenics; they also put these principles into action — and, indeed, extended them — by taking a central role in the Nazi regime’s so-called “euthanasia program.”38 Contemporary memorial sites in Germany and Austria now refer to this part of the Holocaust as "Krankenmorde" (the murder of the sick). Like eugenics, "euthanasia" of the mentally ill was publicly debated in the US at the same time

31 David Deutsch, “Immer mit Liebe: Empathic Violence in Nazi Euthanasia,” Holocaust Studies: A Journal of Culture and History 22, no. 1 (2016), 1-20.

32 Gerrit Hohendorf, Der Tod als Erlösung vom Leiden: Geschichte und Ethik der Sterbehilfe seit dem Ende des 19. Jarhunderts in Deustchland (Göttingen: Wallstein, 2013).

33 Friedlander, The Origins.

34 Francis Galton, Hereditary Genius: An Inquiry Into Its Laws and Consequences (London: Macmillan, 1869).

35 Burleigh, Death and Deliverance.

36 Robert Proctor, Racial Hygiene: Medicine Under the Nazis (Cambridge, Mass: Harvard University Press, 1990).

37 Lifton, The Nazi Doctors.

38 Ernst Klee, “Euthanasie” im NS-Staat: Die “Vernichtung lebensunwerten Lebens” (Frankfurt-am-Main: Fischer, 1983); Friedlander, The Origins. 
as it rose in popularity in Germany, with prominent US neurologist Foster Kennedy ${ }^{39}$ arguing that the "feeble minded" should be killed. ${ }^{40}$ In July 1933, the German Reichstag passed the "Law for Prevention of Hereditary Diseased Offspring” following which "Hereditary Health Courts" mandated sterilisation of several hundred thousand adults of child-rearing age deemed by their doctors as having hereditary diseases. There followed the sporadic murder of disabled children by deliberate overdoses of barbiturates, or combinations of morphine and scopolamine. Following successful experiments with carbon monoxide gas chambers, a centralised process of mass murder of those deemed "life unworthy of life" was organised from Tiergartenstraße 4 in Berlin. The secret operation-Aktion T4-coordinated the identification of victims in institutions in Germany and Austria, their mass transportation to six dedicated killing centres equipped with gas chambers, the disposal of remains, and a process of deception about the manner of death of the victims. Jewish patients were among the first to be killed, regardless of their clinical status or work capacity. ${ }^{41}$ By late summer 1941, growing community awareness of the programme led to public protest, prompting Hitler to order the gassings to halt. Undeterred, many German psychiatrists continued to murder patients-mostly by deliberate overdose or starvation-in a process termed Wilde Euthanasie (decentralised euthanasia). ${ }^{42}$ Many senior psychiatrists participated in Aktion T4, with a number of doctors later participating in coordinated killing of sick prisoners in the concentration camp system under Aktion $14 f 13 .{ }^{43}$ Accounting for the sporadic murders of asylum patients in Nazi occupied Europe, around 300,000 disabled people were killed in the period $1933-1945 .{ }^{44}$ It is noteworthy that after the T4 programme was disbanded, more than 90 per cent of those who worked in it later participated in the extermination camps of Aktion Reinhard, the process of eliminating Poland's Jewish population. ${ }^{45}$

\section{Psychotherapy in the Nazi regime}

The immediate effect of National Socialism on the practice of psychotherapy

39 Foster Kennedy, “The Problem of Social Control of the Congenital Defective: Education, Sterilization, Euthanasia,” American Journal of Psychiatry 99, no. 1 (1942), 13-16.

40 Jay Joseph, “The 1942 'Euthanasia' Debate in the American Journal of Psychiatry,” History of Psychiatry 16, no. 2 (2005), 171-79.

41 Rael Strous, "Extermination of the Jewish Mentally-ill During the Nazi Era-The 'Doubly Cursed,' " Israel Journal of Psychiatry Related Sciences 45, no. 4 (2008), 247-56.

42 Gerhard Schmidt, Selektion in der Heilanstalt, 1939-1945 (Berlin: Springer, 2011).

43 Friedlander, "Physicians as Killers."

44 This estimate is provided by the official memorial to the victims of Nazi euthanasia in Berlin.

45 Klee, “Euthanasie” im NS-Staat. 
was evident in the expulsion of Jewish therapists from practice as part of the Gleichschaltung. The Berlin Psychoanalytic Institute existed within the tradition of Freud and many of its esteemed alumni were Jews. The changes to psychotherapy in the Nazi regime have been documented. ${ }^{46}$ Central to these accounts is the establishment of the so-called Göring Institutes. The exclusion of Jewish therapists and the denouncement of the "Jewish science" of psychoanalysis created an opportunity for Mathias Göring (first cousin of Hermann Göring) to establish a series of psychotherapeutic institutes that practised brief and focal therapies (Kleintherapie), including biofeedback, behavioural modification and some forms of family therapy. In keeping with the instrumental goals of the Nazi regime, the critical shift in psychotherapy was away from the patient growth and introspection sought by psychoanalysis, toward the improvement and enhancement of the health and function of the population.

\section{Psychiatrists in the military}

German psychiatrists were well integrated into the armed forces, particularly the Wehrmacht. The main concern of psychiatrists working in the military under the Nazi regime was war neurosis (Kriegsneurosen), or what would be now considered post-traumatic stress disorder. Each army district had an advisory psychiatrist (Beratender Psychiater) who provided data to the central authorities, including the incidence of different forms of psychological disturbance and problematic behaviours such as self-inflicted wounds, desertion and insubordination. Most psychiatrists working in the Wehrmacht refused to acknowledge Kriegsneurosen as a legitimate clinical concern. ${ }^{47}$ The commonly held assumption was that such problems did not occur in the Wehrmacht due its superior command structure and morale, and successful recruitment and replacement policies. ${ }^{48}$ As part of recruitment processes, psychiatrists advised the Wehrmacht how to exclude unsuitable recruits. ${ }^{49}$ The likelihood is that the comparatively low reported rate of war neurosis was attributable to the success of the Wehrmacht in the first years of the war. ${ }^{50}$ After 1942 and the failures of campaigns in North Africa and the Soviet Union, the rates of psychiatric casualties increased exponentially.

\footnotetext{
46 Cocks, Psychotherapy; Goggin and Brockman-Goggin, Death of a Jewish.

47 Robert Schneider, "Stress Breakdown in the Wehrmacht: Implications for Today's Army,” in Contemporary Studies in Combat Psychiatry, ed. Gregory Belenky (Santa Barbara: Praeger, 1987), 87-101.

48 R. Valentin, Kankenbatallione (Dusseldorf: Droste, 1981).

49 Peter Reidesser and Axel Verderber, Maschinengewehre hinter der Front. Zur Geschichte der deutschen Militärpsychiatrie (Frankfurt am Main: Fischer, 1996).

50 Schneider, "Stress Breakdown.”
} 
Some personnel with war neurosis were diagnosed with organic conditions such as encephalitis and treated in military hospitals as medically ill. Others were either deemed "psychopaths" or malingerers and subject to hard labour in specific units or, in some circumstances, imprisoned or sent to concentration camps. ${ }^{51}$ In cases where a diagnosis of war neurosis was accepted, management derived from the approach of "forward treatment" (immediacy, proximity, expectancy, simplicity, and centrality) developed by American psychiatrist Thomas W. Salmon during World War One. An additional carryover of the treatment of "shell shock" from World War One was the use of the so-called "Kaufmann cure" that involved the administration of electric shocks to traumatised soldiers in order to facilitate a desire to return to the front. ${ }^{52}$ In the Nazi regime, this approach became the specialty of psychiatrist Frederich Panse at the Ensen Hospital near Weimar-the treatment was renamed Pansen. ${ }^{53}$ Panse had a long-standing interest in military psychiatry and had published on themes of compensation neurosis and malingering in soldiers. ${ }^{54}$ Pansen was initially opposed by many in the Wehrmacht and in the health bureaucracy; however, with the escalation of psychiatric casualties in the latter part of the war, this resistance softened.

\section{Part 2-Lessons learnt, ignored and forgotten}

\section{The meaning and understanding of "Holocaust"}

In order to understand the lessons of psychiatry in the Nazi period, it is necessary to consider not only psychiatrists' participation in the Nazi regime, but also the fact that they played a critical role in the "Holocaust." Our approach to the Holocaust as "the seminal ethical event of modernity" 55 or the "paradigm of genocide" necessitating a "new categorical imperative" 56 and contemporary reflection, extends from the analysis of Zygmunt Bauman. Bauman argues that the Holocaust represents both a central moment in Jewish history and the "hid-

\footnotetext{
51 Ibid.

52 Kaufmann, “Die planmäßige Heilung.”

53 Ralf Forsbach, "Friedrich Panse-Etabliert in Allen Systemen: Psychiater in der Weimarer Republik, im 'Dritten Reich' und in der Bundesrepublik,” Nervenarzt 83 (2012), 329-36.

54 Friedrich Panse, "Das Schicksal von Renten-und Kriegsneurotikern nach Erlangung ihrer Ansprüche,” Archiv für Psychiatrie 77 (1926), 61-92.

55 Shmuel Reis and Tomi Chelouche, "Medicine and the Holocaust-Lessons For Present and Future Physicians," Medicine and Law: The World Association for Medical Law 27, no. 4 (2008), 787-804; Colin Tatz and Winton Higgins, The Magnitude of Genocide (Santa Barbara: Praeger, 2016).

56 Theodor Adorno, Negative Dialectics (New York: Seabury Press, 1973).
} 
den face” of modernity. ${ }^{57}$ Key features of Bauman's definition of modernity are the removal of unknowns and uncertainties through control over biology, creation of bureaucracy, enforced rules and regulations, and control and categorisation of individuals leading to a process of exclusion. ${ }^{58}$ The latter is significant in that the origins of the Holocaust exist within the culture-in this case, one characterised by modernist beliefs and values-and therefore can recur under similar cultural circumstances. Along similar lines, Colin Tatz and Winton Higgins describe the Holocaust as the coalescence of the different components of the modern state-infrastructure, bureaucratic hierarchies, and a culture of scientism that legitimated the process. ${ }^{59}$

\section{Bureaucracy in the Holocaust}

Of the various features of modernity, bureaucratisation seems to have been particular important. Max Weber's formulation of the modern bureaucracy in the most recognised. Weberian bureaucracy is characterised by a hierarchical organisation, with delineated lines of authority and fixed areas of activity. ${ }^{60}$ In a bureaucracy, action is taken by neutral officials or functionaries working under specific rules within a hierarchic structure. ${ }^{61}$

For Bauman, one of the critical preconditions of the Holocaust was bureaucratic and industrialised organisation. ${ }^{62}$ This meant that antisemitism and modernity, while necessary, were not sufficient conditions in themselves for the Holocaust. What was needed beyond political will was a rational bureaucracy, as rationalisation was the critical process in enacting genocide. Indeed, the organisational aspects of the Holocaust for Bauman were its defining characteristic. It is evident that the organisational aspects of the Holocaust flourished in the Nazi regime’s “euthanasia” programme. Aktion T4 provided the definitive template of the Holocaust-a centrally controlled bureaucratic process of identification, exclusion and collection of victims, mass transporta-

57 Bauman, Modernity and the Holocaust.

58 This is Bauman's concept of "solid modernity," as against his subsequent development of "late" or "liquid" modernity.

59 Tatz and Higgins, The Magnitude.

60 For Weber, the bureaucratisation of government and society is characterised by a process of "rationalisation" in which traditional values, such as filial or community bonds, are replaced by “outcomes" such as markers of efficiency or economy. Weber did not demonise bureaucracy; indeed, he saw it as an inevitable part of large government. He did, however, describe how it created "technically ordered, rigid, dehumanized society," with profound influences on self-concept and community relationships. For Weber, the modern world was shaped by bureaucratic rationalisation, which creates what he famously proclaimed as the Stahlhartes Gehäuse (iron cage). See Max Weber, The Protestant Ethic and the Spirit of Capitalism (1905; London; Penguin, 2002).

61 Max Weber, Economy and Society (Berkeley: University of California Press, 1922).

62 Bauman, Modernity and the Holocaust. 
tion to dedicated industrialised killing centres arranged in a network, efficient killing and disposal methods, and elaborate deception. The association of bureaucracy and the Holocaust is also at the core of Hannah Arendt's formulation of the criminality of Adolf Eichmann, the prototypic "Schriebtischtäter" (desk criminal). ${ }^{63}$ Arendt's observation was that Eichmann's involvement in the programme of genocide emerged through him operating thoughtlessly and following orders efficiently (even proclaiming his Kantian ethics) ${ }^{64}$ without consideration of the victims. ${ }^{65}$

\section{German medicine and bureaucracy}

It is argued that German modernity, including its relationship to Nazism, was characterised by the persistence of aristocratic power structures and under-developed liberal democratic institutions. ${ }^{66}$ The series of revolutions in Europe in 1848, in which liberalism became a political reality, failed in Germany. This meant that the authoritarianism of aristocracy and Prussian militarism were preserved, and that modern German social institutions and professions evolved with a particular relationship to the authority of the state. Most notably, loyalty to the state was placed above all else in any professional ethics. Kühne argued that the Nazi state had achieved an even more material manifestation of the Volksgemeinschaft (people's community) through exclusion of non-Aryans (and genetic inferiors) and that this enabled such ethical inversions in the professions as well as the community. ${ }^{67}$

The 1946-1947 Doctors' Trial in Nuremberg, ${ }^{68}$ and a number of later prosecutions in West Germany, provide some insight into the individual and collective motivations of the German medical profession and its relationship

63 Hannah Arendt, Eichmann in Jerusalem: A Report on the Banality of Evil (London: Faber \& Faber, 1963).

64 In Arendt's Eichmann in Jerusalem, she notes his justifications for devotion to duty by his stating he had been schooled in Kant's categorical imperative.

65 Not everyone accepts this portrait of Eichmann, which is challenged by the account of Benjamin Murmelstein, an elder of the Jewish leadership (Judenrat) in the Theresienstadt concentration camp, who claimed he witnessed Eichmann's extreme antisemitism during Kristallnacht in Vienna in November 1938, proclaiming to filmmaker Claude Lanzmann: “Eichmann was not banal, he was a demon.” Later analysis of Eichmann's correspondence while in Argentina, and in particular his scheming and his endorsement of his crimes to fellow émigré Nazis in South America, also challenge Arendt's argument. See Bettina Stangneth, Eichmann Before Jerusalem (New York: Vintage, 2011). Stangneth does not reject specifically Arendt's concept of the banality of evil—she argues that Eichmann was not a good example of it. His particular evil was anything but banal.

66 Barrington Moore Jr., Social Origins of Dictatorship and Democracy: Lord and Peasant in the Making of the Modern World (Boston: Beacon Press, 1966).

67 Thomas Kühne, Belonging and Genocide: Hitler's Community, 1918-1945 (New Haven: Yale University Press, 2010).

68 Nuremberg Military Tribunal 1: USA v Karl Brandt et al. (the trial of 23 alleged perpetrators of unconsented and cruel experiments and the "euthanasia” programme). 
to the Nazi regime and its genocidal programme. The special advisor to the Nuremberg Tribunal, Austrian-born émigré psychiatrist Leo Alexander, reflected later on his observations of the trial, arguing that there were two critical moral failings underlying the crimes of the "Nazi doctors." ${ }^{\text {"69 }}$ First, the process began with the subtle shift of attitudes of physicians about a relative value of life. Second, Alexander argued that the physicians working in the Nazi regime drifted from an approach of an "essentially maternal and religious idea" of care, to an assumption of responsibility for cure or restoration of function. This, in turn, emerged as a shift in emphasis of medical practice from serving the individual to serving the state. This was the ultimately malignant influence of bureaucracy and Bauman's modernity on the medical profession.

In the German medical profession, there existed two traditions of Sorge (care). Fürsorge was the clinical care of the individual, as against Vorsorge, meaning public health and preventive care. Under Gleichschaltung, the focus of German medicine aligned with the bio-political aims of the Nazi regime and a duty of Vorsorge became the moral obligation of the profession. ${ }^{70}$ In keeping with Lifton's notion of National Socialism as a form of "applied biology," the medical profession was tasked with the health of the Volk (the homogenous Aryan population). Under National Socialism, illness and health became a critical part of the Volkskörper metaphor (the body of the German people), considered "a bodily metaphor or an expression of the organic creed characteristic of fascist ideology." "71 Health and illness became a "focal point for the myriad larger social, economic, and psychological concerns of the era." ${ }^{\text {,2 }}$ Such metaphors enabled racist and other exclusionary discourses to flourish. This legitimated the Nazi regime's later programmes of persecution of the weak or undesirable, and the eliminative genocide of the Holocaust. The emphasis on the metaphors of health and illness allowed Jewish people to be defined as "cancer" or "bacillus" and their elimination as a form of medical cure. This process also placed the medical profession and its bureaucratic structures as a critical actor in the Nazi regime's programmes of persecution and genocide.

The transition in German medicine from Fürsorge to Vorsorge began during the chancellorship of Bismarck (1871-1890). Medicine gradually became a state-controlled and state-sponsored enterprise. Oncologist Erwin Leik de-

69 Leo Alexander, “Medical Science Under Dictatorship,” New England Journal of Medicine 241, no. 2 (1949), 39-47.

70 Warren T. Reich, "The Care-Based Ethic of Nazi Medicine and the Moral Importance of What We Care About,” American Journal of Bioethics 1, no. 1 (2001), 74-84.

71 Boaz Neumann, "The Phenomenology of the German People’s Body (Volkskörper) and the Extermination of the Jewish Body,” New German Critique 36, no. 1 (2009), 149-81.

72 Geoffrey Cocks, The State of Health: Illness in Nazi Germany (New York: Oxford University Press, 2012). 
spaired of the advent of socialised medicine in Germany, supervised by the state and also by the market, believing that it had compromised individual care and created a generation of Kässenartze (cashier doctors) ${ }^{73}$ He described how doctors were compelled by social insurance systems into a mechanised and overly scientifically focused practice that endorsed cost constraint and community and economic perspectives at the expense of patient care. ${ }^{74}$ Under the Nazi regime, the German medical profession was enjoined in a social and economic transformation of the population through the valorisation of Vorsorge and the privileging of medical science in public policy-making. ${ }^{75}$ In the first instance, this manifested in the persecution of the weak through involuntary sterilisation and later Krankenmorde, although, as the groundbreaking work of Robert Proctor demonstrates, this also involved revolutionary change in public health. ${ }^{76}$ Beyond the metaphoric surgical excision of Jews, the disabled and other "undesirables," the Nazi regime sought to eliminate cancer in the population through a raft of initiatives aimed at reducing smoking, alcohol and environmental pollutants, and encouraging healthier plant-based diets. Proctor sees this as a historical first; the implementation at the individual level of initiatives aimed at enhancing the productivity and, ultimately, war-making capacity of the Volk. This form of modern public health was not "in spite of fascism, but in consequence of fascism., 77

This focus on the care of the population represented a particular version of "German modernity" - one that was at odds with the liberal prioritisation of the individual self, and instead linked the entitlement to health care to the capacity for productivity in service of the greater German people's community or Volksgemeinschaft. ${ }^{78}$

None of this is to suggest that individual motivations were irrelevant in driving the actions of psychiatrists under the Nazi regime. As mentioned previously, participation in the regime was driven by myriad factors including ideology, obedience, ambition, fear and opprobrium. However, German modernity-with its particular form of bureaucracy—clearly played an important role.

\footnotetext{
73 Mary Seeman, “Psychiatry in the Nazi Era,” Canadian Journal of Psychiatry 50, no. 4 (2005), 218-25.

74 Ibid.

75 Jennifer Leaning, “War Crimes and Medical Science,” British Medical Journal 313 (1996), 1413-15.

76 Robert N. Proctor, The Nazi War on Cancer (Princeton: Princeton University Press, 1999).

77 Ibid., 249.

78 Cocks, The State.
} 


\section{"Biopower" and the State}

As we noted earlier, one component of modernity for Bauman was control over nature and biology. This recruits biological and biomedical disciplines as executors of, or at least part of, modernity. Our thesis is that the significance of the Holocaust to contemporary medical ethics, and in particular psychiatric ethics, is usefully framed through the concept of "biopower"-a concept that, for reasons we will explain later, is particularly salient in forms of modernity that are characterised by the bureaucratisation of medicine.

The term "biopouvoir" (biopower) appeared initially in Michel Foucault's work, History of Sexuality (1976), and was later developed in a series of lectures he gave at the College de France. The core idea in Foucault's construct of biopower is the integration of sovereign power with biological science and the reformulation of politics as, ultimately, control over life. Foucault introduced the term "governmentality" to provide a critique and modification of the premodern notion of power being the exercise of coercion by a sovereign power or ruling class and, in particular, the means by which this power is exercised. In essence, governmentality through biopower seeks to either "make live" or "let die" - an inversion of the ancient legal apparatus of Roman law of $\mathrm{Pa}$ ter familias that would be "let live and make die."79 Related to this, Foucault described a shift from "sovereign" power to "discursive" power-in this formulation power is generated by a particular discourse (evident in a "discursive formation”) in the absence of a particular "ruling class." ${ }^{80}$ Foucault considered a "discourse" as an institutionalised way of speaking or writing about reality that defines what can be intelligibly thought and said about the world and what cannot. A discourse creates a form of truth, rather than discovering it as it is.

Within modernist societies, bureaucracies create contexts that are particularly ripe for the exercise of biopower because a critical component of modernity is the control of biology, inevitably co-opted into a bureaucratised medical profession. According to Foucault, biopolitical power emerges with particular force and efficiency in the context of the modern capitalist nation state where it is exercised in, for example, interventions to effect control over fertility, vaccination, screening and treatment of disease, diet or pharmaceutical manipulation. Biopolitical power is exercised at both the level of the

79 Michel Foucault, The History of Sexuality, Volume One: An Introduction (London: Penguin, 1981), 137.

80 This is a manifestation of Foucault's formulation of the indistinguishability of power from knowledge. Foucault considers knowledge is always an exercise of power and power always a function of knowledge. See Michel Foucault, The Archaeology of Knowledge, trans. A.M. Sheridan Smith (New York: Pantheon Books, 1969). 
individual and the population (what he terms the "massification" of individuals into a population).

The modern state's scientifically inspired "disciplinary institutions" replaced the pre-modern power of the sovereign over both the individual and groups in the population, through a technologically driven process of behaviour control. ${ }^{81}$ The dissonant observations of the Nazi "war on cancer,"82 juxtaposed with the persecution of the disabled, can be reconciled within the framework of biopower. In both instances, the medical profession acts as the executive in the process aimed to improve the economic situation (or in the case of the Nazi regime, the war-making capacity) of the population.

It has been argued that Foucault's notion of Dispositif (loosely translated as an "urgent need") provides a pretext to the exercise of biopower by the state. ${ }^{83}$ Dispositif can be conceptualised as a network of different discourses, institutional responses or laws in response to a defined or perceived crisis. ${ }^{84}$ An obvious example includes quarantine or regional isolation in the case of infectious disease. In a contemporary example of biopower and the Dispositif, the problem of the obesity "epidemic" arises from construction of ideal biological parameters consistent with a notion of "health," as defined in this case by weight, adiposity or other biochemical markers. ${ }^{85}$ The application of biopower by the state facilitates urgent interventions in public and individual health, arguably targeting the financial burden posed by the phenomenon and its threat to the state's finances. Our argument is that the 1930s' constructs of racial hygiene or eugenics represent equally apposite examples of Dispositif - the perceived threat to the population posed by purportedly inferior racial and genetic stock initiated a state-directed programme of registration, exclusion, sterilisation and mass murder, unprecedented in terms of scale and technological sophistication. The Nazi regime utilised eugenics and racial hygiene to legitimate its use of extreme forms of biopower through its "euthanasia" programme and subsequent racially based eliminative genocides in Europe. ${ }^{86}$

\footnotetext{
81 Michel Foucault, Security, Territory, Population: Lectures at the Collège De France, 1977-1978 (New York: Palgrave, 2007).

82 Proctor, The Nazi War, 249.

83 Christopher Mayes, The Biopolitics of Lifestyle: Foucault, Ethics and Healthy Choices (New York: Routledge, 2016).

84 Ibid.

85 Mayes, The Biopolitics.

86 The concept of "biopower" as a means of formulating the behaviour of nurses in the T4 programme has been explored by Thomas Foth, whose work also situates "Dispositif" in the asylum setting. See Thomas Foth, “Analyzing Nursing as a Dispositif Healing and Devastation in the Name of Biopower.” PhD thesis, University of Ottawa, 2011; Thomas Foth, “Understanding 'Caring' Through Biopolitics: The Case of Nurses Under the Nazi Regime,” Nursing Philosophy 14, no. 4 (2013), 284-94.
} 
As stated earlier, eugenics had a long history in Germany and other democratic societies. It was popular across the political spectrum in the Weimar parliament in Germany (1919-1933). There was also enthusiasm for eugenic ideas in the middle and professional classes, part of a so-called "techno-bureaucratic intelligentsia." ${ }^{87}$ Eugenic societies were influential in numerous other countries, most conspicuously the USA. The state of Indiana had passed the first compulsory sterilisation law in 1907. Until the 1960s, 29 other US states enacted similar laws. German and American eugenic institutions collaborated closely until the outbreak of the war. American eugenicists were profoundly influential in the formulation of the 1924 US federal Immigration Act. ${ }^{88}$ Prominent American physicians advocated the "euthanasia" of "feebleminded" patients, ${ }^{89}$ and it was only when the mass murder of the disabled under Nazism became apparent that German and other western eugenic movements parted company. ${ }^{90}$ The attempted "psychiatric genocide" of people with schizophrenia in Germany during the Nazi period failed: the prevalence of the disorder actually increased after the war.

Eugenic notions have served as the basis of state policy in a number of countries in the post-war era and represent continuations of this form of biopower. In China, for example, the 1995 Maternal and Infant Health Law forbade people carrying heritable mental or physical disorders from marrying, and promoted mass prenatal ultrasound testing for birth defects. Then Chinese Premier, Deng Xiao Ping, also encouraged social and economic policies to ensure educated and successful young Chinese would meet and procreate. The since revised "one child policy" was another manifestation of the process. In Singapore, the Family Planning and Population Board (FPPB) advocated population control. In the 1970s, Singaporean social and economic policies sought to increase the reproduction rate of educated and successful women and reduce that of low-paid, uneducated women. In most post-industrial liberal democratic societies, tacit forms of eugenic-based biopower are found in state-funded and professionally-endorsed routine prenatal screening for foetal abnormality. As a result of these programmes, for example, numerous studies indicate that the vast majority of pregnancies with Down Syndrome are terminated at the point of pre-natal diagnosis. ${ }^{91}$ It has also been averred that

87 Burleigh, “The Legacy.”

88 Adam Cohen, Imbeciles: The Supreme Court, American Eugenics, and the Sterilization of Carrie Buck (New York: Penguin, 2016).

89 M. Louis Offen, “Dealing With 'Defectives': Foster Kennedy and William Lennox On Eugenics,” Historical Neurology 61, no. 5 (2003), 668-73.

90 Edwin Black, War Against the Weak: Eugenics and America's Campaign to Create a Master Race (New York: Basic Books, 2003). 
legitimating termination of pregnancies on the basis of specific evaluative "criteria" enables discrimination against those who live with Down Syndrome or other disabilities. ${ }^{92}$

\section{"Thanatopolitics"}

As shown in the Nazi regime, in extreme authoritarian settings biopower becomes the literal question of life and death. This is what Foucault and later writers termed "Thanatopolitics." Foucault considered genocide as the logical extension of biopower through the revisitation of the right of the sovereign to kill, an exercise of coercive power at the level of life, species, race and population. ${ }^{93}$ Foucault saw that genocide was the ultimate expression of this.

Despite the traditional definition of genocide interrogating the deliberate elimination of a national, ethnical, racial or religious group, many in the field of disability studies have argued that "disability" is as much a social category as race. ${ }^{94}$ Moreover, any reading of the history of the first part of the twentieth century in the United States or Europe sees the categories of "disability" and "race" as manifestations of biological inferiority and therefore the pretext for exclusion and ultimately annihilation. The firm nexus between eugenics and racism in the United States and Europe in the first part of the twentieth century is a core premise of what has been dubbed the "eugenic Atlantic."95 The genetic and racially inferior fall into the same category and so therefore does their elimination. The Krankenmorde is therefore arguably as much a genocidal act as the Shoah. It is important to recognise that of the German victims of the Nazi regime, the more than 200,000 people with disabilities who were murdered represent the group with the highest mortality. ${ }^{96}$

Thanatopolitics is at the core of the work of philosopher Giorgio Agamben. Agamben defined the threshold of biological modernity as the point where the species and the individual as living bodies becomes the focus of politics- the state and, by extension, the focus of the state bureaucracy, becomes a "biomass" of population, or, as in the case of the Nazi regime, the Volk. Agamben

\footnotetext{
91 Brian Skotko, "With New Prenatal Testing, Will Babies With Down Syndrome Slowly Disappear?” Archives of Disease in Childhood 94, no. 11 (2009), 823-26.

92 Alicia Ouellette, “Selection Against Disability: Abortion, ART, and Access," Journal of Law, Medicine and Ethics 43, no. 2 (2015), 211-23.

93 Foucault, The History.

94 Catherine Kudlick, "Disability History: Why We Need Another Other,” American Historical Review 108, no. 3 (2003), 763-93.

95 David Mitchell and Sharon Snyder. "The Eugenic Atlantic: Race, Disability, and the Making of an International Eugenic Science, 1800-1945,” Disability and Society 18, no. 7 (2003), 843-64.

96 According to the US Holocaust Memorial Museum, the death toll for German Jews was around 180,000.
} 
makes use of the ancient figure of "Homo Sacer"97 as a metaphor for those excluded from society and its protections: living within the law but not protected by law. This creates a situation redolent of the ancient concept of "bare life"-life without the privileges or rights of citizenship. ${ }^{98}$

For Agamben, the Holocaust was the fullest realisation of biopower and the concentration camp its ultimate manifestation. Agamben argued that when the state shifts into an authoritarian mode, in circumstances of perceived or manufactured threat, it creates what he terms "states of exception."99 This is a state of virtual war on certain parts of the population and a means of elimination-social exclusion and starvation were forms of biopower used against "undesirables" and enemies of the Nazi regime. The particular obsession of the Nazi regime with food, and the use of starvation as a means of control and murder, demonstrates a particular manifestation of a form of biopower expressed through thanatopolitics. ${ }^{100}$ The Musselmänner of the concentration camps, the diseased and starved figures of the Polish ghettos, or the inmates of starvation houses in "de-centralised euthanasia" centres are reduced to bare life in a biologically-driven state of exception. Agamben sees this phenomenon in the present day in Guantanamo Bay or the refugee camps and detention centres of Europe (and, we would argue, the Pacific).

\section{The psychiatric profession and the state}

To eschew a Hippocratic tradition and then be enjoined in an exercise of biopower, the medical profession and its specialties must realise a form of professional ethic. The complex relationship between the psychiatric profession in Germany and the Nazi regime has been analysed from multiple perspectives. ${ }^{101}$ A critical dimension to the analysis of this period is that of professional ethics in psychiatry. ${ }^{102}$ "Professional ethics," as contrasted with particular normative theories of ethics such as utilitarianism or virtue ethics, situates the psychiatrist as moral agent within the context of a complex network of relationships, laws and obligations with the community.

\footnotetext{
97 Agamben's use of Homo Sacer (or the "sacred man") refers to the status of being outside protection of the law or excluded from society. It is a complex concept with multiple examples throughout history.

98 Giorgio Agamben, State of Exception, trans. Kevin Attell (Chicago: University of Chicago Press, 2005).

99 Ibid.

100 Gesine Gerhard, Nazi Hunger Politics: A History of Food in the Third Reich (New York: Rowman and Littlefield, 2015).

101 Lifton, The Nazi Doctors; Klee, "Euthanasie” im NS-Staat.

102 Michael Robertson and Garry Walter, "Overview of Psychiatric Ethics I: Professional Ethics and Psychiatry,” Australasian Psychiatry 15, no. 3 (2007), 201-06.
} 
A "profession" is a group possessed of a certain expertise, knowledge and set of skills that applies these in service of the "greater good," usually of the community. ${ }^{103}$ In exchange, the professional group is afforded status, material reward and autonomy. This arrangement is a form of "social contract" that, through laws, negotiated binding arrangements or policy applications, effectively trumps other approaches to moral deliberation and action by the professional group. ${ }^{104}$ It is in the nature of such arrangements to privilege the interests of the community over the individual, which frequently places the professional's obligations to the individual patient in conflict with obligations to the community under the professional social contract. In such a situation, the Hippocratic injunction to do no harm may need to be abandoned. ${ }^{105}$

This creates a situation of a "dual role dilemma."106 The concept of dual role dilemma originates from the perceived conflict of obligations forensic psychiatrists have to both impartiality to the court and the Hippocratic obligations to the individual patient. ${ }^{107}$ It can be argued that most dilemmas in psychiatric ethics may be framed as variants of the dual role dilemma, many of which arise from conflicting obligations between the psychiatrist's obligations under the professional social contract and duties towards the individual patient.

Leo Alexander highlighted in his analysis of the Doctor's Trial in Nuremberg 1946-1947 that the critical step in the pathway to the crimes perpetrated by psychiatrists under the Nazi regime was a shift from individual care to that of productive capacity or economic utility. ${ }^{108}$ The "useless eaters" destined for death in the T4 programme were thus defined by the cost of their existence, rather than their individual value as human beings. Karl Brandt, Hitler's physician, coordinator of the T4 programme and lead defendant in the doctor's trial, highlighted this dual role dilemma in the seemingly conflicted statements he made in his defence. On the one hand he proclaimed: "Any per-

\footnotetext{
103 "Medical Professionalism in the New Millennium: A Physician Charter," Annals of Internal Medicine 136, no. 3 (2002), 243-46.

104 Robertson and Walter, "Overview of Psychiatric."

105 Allen R. Dyer, Ethics and Psychiatry: Toward Professional Definition (New York: American Psychiatric Press, 1987).

106 Michael Robertson and Garry Walter, "Psychiatric Ethics and the 'New Professionalism.' ” in Psychiatry's Contract With Society: Concepts, Controversies, and Consequences, eds. Dinesh Bhugra, Amit Malik and George Ikkos (London: Oxford University Press, 2010), 221-39.

107 Philip Candilis, Richard Martinez and Christina Dording, "Principles and Narrative in Forensic Psychiatry: Toward a Robust View of Professional Role," Journal of the American Academy of Psychiatry and the Law 29, no. 2 (2001), 167-73.
}

108 Alexander, "Medical Science.” 
sonal code of ethics must give way to the total character of the war."109 On the other, he provided rationalisations about his actions being motivated by the relief of suffering:

Would you believe that it was a pleasure to me to receive the order to start euthanasia? For fifteen years I had labored at the sick-bed and every patient was to me like a brother, every sick child I worried about as if it had been my own. ... And thus I affirmed euthanasia. I realize the problem is as old as man, but it is not a crime against man nor against humanity. Here I cannot believe like a clergyman or think as a Jurist. I am a doctor and I see the law of nature as being the law of reason. For that grew in my heart the love of man and it stands before my conscience. ${ }^{110}$

\section{Conclusion}

Throughout this essay, we have reflected upon how the German psychiatric profession was enrolled in an enterprise on behalf of the state and the health of the Volk, in exchange for unprecedented power and status in the Nazi regime. As an instance of professional ethics, the obligation to the collective (as we have argued, a malignant application of biopower in the origin of genocide) creates a situation of doctors becoming "healer killers" and instruments of genocide. ${ }^{111}$ A similar dual role dilemma born of professional ethics emerged in the Soviet Union several decades later through the persecution of political dissidents by psychiatric diagnosis and restraint, ${ }^{112}$ and subsequently in China through the persecution of Falun Gong practitioners in forensic psychiatric hospitals. ${ }^{113}$ In all three instances, the obligations of the profession to the community, represented by an authoritarian or totalitarian state, creates a diabolical dual role dilemma.

The moral analysis of the history of the Nazi regime needs to move beyond normative comparisons with an "outlier" period in the history of psychiatry, that is, "what the Nazis did." The conceptualisation of the Holocaust as an enduring possibility in Western culture is an important precondition of any ex-

109 Charles Hamilton, Leaders and Personalities of the Third Reich: Their Biographies, Portaits, Autographs, Volume One (San Jose: James Bender Publishing, 1984).

110 Ulf Schmidt, Karl Brandt: The Nazi Doctor: Medicine and Power in the Third Reich (London: Continuum Books, 2007).

111 Lifton, The Nazi Doctors.

112 Sidney Bloch and Peter Reddaway, Soviet Psychiatric Abuse: The Shadow Over World Psychiatry (London: Gollancz, 1983).

113 Sunny Lu and Viviana Galli, "Psychiatric Abuse of Falun Gong Practitioners in China," Journal of the American Academy of Psychiatry and Law 30 (2002), 126-30. 
ploration of the period. As Paul Rabinow and Nikolas Rose have argued, the Holocaust is not "an exceptional moment of throwback to a singular barbarianism, but an enduring possibility intrinsic to the very project of civilization and the law." 114 If we accept that the culture that produced the Holocaust remains the context of the practice of psychiatry, then the contemporary significance of the period requires deeper analysis. Eugenics and euthanasia must be reconceptualised and, in our analysis, the prism of biopower and thanatopolitics are among the most valid ways to do so. The proclamations of international medical groups and the public atonement of those professionals implicated in these crimes are important historical events, but on their own do not enlighten fully the true significance of this period to psychiatry. If one accepts that what happened under the Nazi regime was an extreme form of dual role dilemma-for example, the application of a highly malignant process of the exercise of biopower - then current dilemmas in psychiatric ethics need to be constructed along similar lines. Whether this concerns debates around mental health policy, medicalisation of problems of life, or contemporary biologically based conceptualisations of disability and mental illness, the dual role dilemma remains a function of the empowerment of the psychiatric profession by the community and the expectations that arise from it. If the key participants of this exceptional period in history remain framed as evil doers, indifferent bystanders and heroic resisters, such lessons are lost, forgotten or unlearnt. 